\title{
The Impact of Strategic Management on Organisational Growth and Development (A Study of Selected Manufacturing Firms in Anambra State)
}

\author{
Muogbo U .S. \\ Department Of Business Administration Anambra State University Igbariam Campus Nigeria
}

\begin{abstract}
The study investigated the impact of strategic management on organizational growth and development of selected manufacturing firms in Anambra State. 63 respondents selected from 21 manufacturing firms across the three senatorial zones of Anambra State were sampled (3 from each firm). The study used descriptive statistics (frequencies, mean, and percentages) to answer the four research questions posed for the study. The Chi-Square was used to test the three hypotheses that guided the study. Results from the analysis indicated that strategic management is not common among the manufacturing firms in Anambra State; that the adoption of strategic management has significant effect on competitiveness and also influences manufacturing firms; that strategic management has effect on employee's performance and that its adoption has significantly increased organizational productivity of manufacturing firms; also, it enhances structural development of manufacturing firms. The study thus concluded that though strategic management is not yet a common business practice among manufacturing firms in Anambra State, it has been identified as veritable tool for improving the competitiveness, performance levels, and structural development of manufacturing firms in Anambra State in particular and Nigeria in general. The researcher recommended that entrepreneurial centre and business schools in Nigeria should incorporate strategic management principles into their curricula. This will engender sound managerial know-how and boost the performance and competiveness of firms in Nigeria. Also, further studies should be carried out in Nigeria to investigate the causes on non-adoption of strategic management in Anambra State in particular and Nigeria in general. The causes of this when known and curbed, will enable small and medium scale industries in Nigerian to become more competitive in boosting the development of Nigerian economy.
\end{abstract}

Key Words: Strategic management, Employee Performance. Structural Development, Organisational Performance, Economic Development.

\section{Background to the study}

I. Introduction

Economic environment is changing rapidly and this change is characterized by such phenomena as the globalization, changing customer and investor demands, ever-increasing product-market competition. To complete successfully in this environment, organizations continually need to improve their performance by reducing cost, innovating products and processes and improving quality, productivity and speed to market. "Strategic management is an ongoing process that evaluates and controls the business and the industries in which the company is involved, assesses its competitors and set goals and strategies to meet all existing and potential competitors, and then reassess each strategy annually or quarterly (ie regularly) to determine how it has been implemented and whether it has succeeded or needs replacement by a new strategy to meet charged circumstances, new technology, new competitors, a new economic environment, or a new social, financial or political environment" (Lamb, 1984). Achieving a competitive advantage position and enhancing firm performance relative to their competitors are the main objectives that business organizations in particular should strive to attain. (Raduan, Jegak, Haslinda and Alimin, 2009).

Strategic management can depend upon the size of an organization, and the proclivity to change of its business environment. Therefore, a global transnational organization may employ a more structured strategic management model, due to its size, scope of operations, and need to encompass stakeholder views and requirement.

Major management theories such as those of Chandler (1962) and Child (1972), both cited in Meier, O'Toole, Boyne and Walker (2012) emphasized that private firm can exercise strategic choice, even in the face of external constraints. The way and manner they face strategic issues can affect the overall growth and development of the organization. It goes without saying that the strategic framework must also address fundamental issues such as resource base, infrastructure constrains, appropriate level of technology and raw materials input. 


\subsection{Statement of problem}

The performance of organizations has been the focus of intensive research efforts in recent times. How well an organization implements its policies and programs and accomplishes its strategic intent in terms of its mission and vision is of paramount concern. Managers in both private and public organizations are becoming increasingly aware that a critical source of competitive advantage often come from indigenous product and services, best public relations strategy state-of-the-art technology and having an appropriate system of attracting and managing the organizations human resources.

From the foregoing, and looking at today's trend, it is evident that the space of change in our business environment presents fresh challenges daily. Therefore, a panacea must be found for the manufacturing subsector, if it must adequately meet its challenges. Various firms, therefore, need to come up with the applications of innovative ideas to create unique brands, customers-friendly products/services that will bring about competitive advantages in terms of brand preference and customer confidence.

Despite these, no research work has targeted to investigate the impact of the broad subject of strategic management on organizational growth and development in Nigeria. Existing studies in Nigeria, aimed at human resource development (eg Oladipo and Abdulkadir, 2010; Oladipo and Abdulkadir, 2011; Abdulkadir, 2012). Related studies on this study were on strategic planning (an off shoot of strategic management) (see Ilesanmi, 2011 and Akinyele \& Fasogbo, 2007). Of these studies in Nigeria, none accessed the impact of strategic management of planning on manufacturing sub-sector of the economy. To this effect, this study attempts to empirically analyze how strategic management can be used by manufacturing firms in Anambra State to effectively derive plans for growth and development.

\subsection{Objectives of the study}

The general objective of the study is to investigate the place of strategic management in improving corporative performances among the manufacturing firms in Anambra State of Nigeria. The specific objectives are to:

1. Determine the extent to which strategic management is practice by manufacturing firms in Anambra State of Nigeria.

2. Determine the relationship between the level of competition and adoption of strategic management.

3. Assessed the relationship adoption of strategic management and organizational performance.

\subsection{Research question}

1. Is strategic management practiced by manufacturing firms in Anambra State of Nigeria?

2. What is the effect of strategic management on level of competition?

3. What is the effect of strategic management on organizational performance?

\subsection{Hypothesis}

The following null hypotheses guided the study:

1. Adoption of strategic management does not have effect on the level of competition of manufacturing firms.

2. Adoption of strategic management does not have significant effect on organizational performance.

3. Adoption of strategic management does not have significant effect on structural development of an organization.

\section{Theoretical framework}

\section{Literature Review}

\subsection{Overview of Strategic Management Theory}

Strategic management is the process and approach of specifying an organization's objectives, developing policies and plans to achieve and attain these objectives, and allocating resources so as to implement the policies and plans. In other words, strategic management can be seen as a combination of strategy formulation, implementation and evaluation (David, 2005; Haim Hilman Abdullah, 2005; Mohd Khairuddin Hashim, 2005; Zainal Abidin Mohamed, 2005). According to Radua, Jegak, Haslinda, and Alimin (2009), strategic management theories stem mainly from the systems perspective, contingency approach and information technology approach. Following David (2005) and Mohd Khairuddin Hashim (2005), among the common strategic management theories noted and applicable are the profit-maximizing and competition-based theory, the resource-based theory and contingency theory.

2.1.1 The profit-maximizing and competition-based theory, which was based on the notion that business organization main objective is to maximize long term profit and developing sustainable competitive advantage over competitive rivals in the external market place. The industrial-organization (I/O) perspective is the basis of this theory as it views the organization external market positioning as the critical factor for attaining and sustaining competitive advantage, or in other words, the traditional $\mathrm{I} / \mathrm{O}$ perspective offered strategic 
management a systematic model for assessing competition within an industry (Porter, 1981). On the other hand, the resource-based theory which stems from the principle that the source of firms competitive advantage lies in their internal resources, as opposed to their positioning in the external environment. That is rather than simply evaluating environmental opportunities and threats in conducting business, competitive advantage depends on the unique resources and capabilities that a firm possesses (Barney, 1995). The resource-based view of the firm predicts that certain types of resources owned and controlled by firms have the potential and promise to generate competitive advantage and eventually superior firm performance (Ainuddin et al., 2007).

However, the contingency theory draws the idea that there is no one or single best way or approach to manage organizations. Organizations should then develop managerial strategy based on the situation and condition they are experiencing. Therefore, in this study, besides the systems perspective, contingency approach and the other main strategic management theories mentioned above, the resource-based theory or view (RBV) of the firm's competitive advantage in particular will be the underlying theoretical foundation applied and fundamental basis of the variables and their ensuring relationships that are being studied. This is because of the nature of the Nigeria polity that exposes all firms to high cost of doing business in terms of internal power generation and high level corruption. As a result of this, this study will focus especially on the internal attributes (i.e. resources, capabilities and systems) of the organization towards attaining competitive advantage. Hence, it justifies the adoption of RBV as the main research tenet.

\subsection{Empirical Literatures}

Strategic management is an important aspect of management that elicits research interest among scholars and practitioners. This can be attributed to the universal application of this aspect of management discipline. One of the recent conceptual studies in Nigeria (Ujunwa \& Modebe, 2012) advocated for the adoption of strategic management approach in ensuring capital market efficiency following the perceived pivotal role the capital market in economic development. The strategic measure they reviewed ranged from effective regulation to achieving favourable macroeconomic environment. They posited that these strategies will not only promote the efficiency of the capital market, but will leverage the role of the capital market in promoting economic growth.

Askarany and Yazdifar (2012), investigating the diffusion of six proposed strategic management tools of the past few decades through the lens of organizational change theory, examined the relationship between the adoption of these techniques and organizational performance in both manufacturing and non-manufacturing organizations in New Zealand. The findings suggest a significant association between the diffusion of these relatively new strategic management tools and organizational performance.

Gichunge (2007) examined the effect of formal strategic management on organizational performance of medium sized manufacturing enterprises in Nairobi, Kenya. It examined the extent to which formal strategic management is adopted by medium sized manufacturing enterprises in Kenya and investigated the effect of various administrative/legal factors on the extent to which formal strategic management are adopted. It also determined the relationship between level of competition and adoption of formal strategic management and investigated the effect of administrative/legal factors on organizational performance. Finally the study assessed the relationship between adoption of formal strategic management and organizational performance. The data was analyzed statistically using the SPSS and R packages through tabulation, proportions and logit analysis. Results showed that the MEs have not adopted any formal strategic management. It is consistent with past studies that administrative/legal factors affect both adoption of formal strategic management and organizational performance. Competition also influences adoption of formal strategic management. Organizations with formal strategic management perform better than those without formal strategic management.

\subsection{Research Design}

\section{Research Methods}

This study used a descriptive survey design. The purpose of using descriptive surveys was to collect detailed and factual information that describes. Data was collected based on the concepts defined in the research model and hypothesis tested. The study is a descriptive survey because it adopted the use of questionnaires aimed at finding the effect of strategic management on organizational growth and development.

\subsection{Sample And Sampling Techniques}

Cluster sampling was used to select equal Number of manufacturing firms from each sample cluster in the study (see Appendix 2). Meier, O'Toole, Boyne and Walker (2012) posited that strategy can be characterized as senior managers' response to the constraints and opportunities that they face. Therefore, the study will use only the senior staff of the firms. The three prospective respondents that formed the sample are the manager, the account, and the production manager since it would be difficult to reach the Chief Executive 
Officers the sample comprised 63 management staff from 21 selected manufacturing firms operating in Anambra State, Nigeria as shown in Appendix.

The data collection instrument used was a structured questionnaire because questionnaires are extremely flexible and could be used to gather information concerning almost any topic, from a large or small number of people (Moore, 1987 cited in Olatokun and Gbinedion, 2009). The questionnaire was specifically designed to accomplish the objectives of the study. The questionnaires were divided into four sections. Section A collected basic demographic information regarding the respondent such as gender, age, academic qualification, location, cadre, and working experience,. Section B sought to determine the extent to which strategic management is practiced by manufacturing firms; Section C captured information on factors that determines strategic management intensity; Section D captured information on the relationship between level of competition and adoption of strategic management; section $\mathrm{E}$ assessed information on the relationship between adoption of strategic management and organizational performance; while section F deals on the Relationship between strategic management and structural development of an organization.

Section A consisted of closed-ended questions. Sections B to F used a structured 4- points modified likert scale battery of strongly agree (4), agree (3), disagree (2) and strongly disagree (1) in line with Atiku Genty and Akinlabi (2011). The respondents were asked to indicate the extent to which they agree/disagree with various statements.

\subsection{Validity of the Instrument}

Content validity of a scale is qualitative (Akyol and Akehurst, 2003). Therefore, validity of the instrument was ascertained by test experts to ascertain its content before its use. The experts were three senior lecturers with $\mathrm{PhD}$ from the Faculty of Management Sciences, Anambra State University, Igbariam Campus. The validity of the instrument was ascertained by giving out copies of the draft questionnaires, research questions, hypothesis, alongside with the purposes of the study. The suggestions and recommendations of the experts were used to correct the drafted questionnaire.

\subsection{Method of Data Analyses}

The descriptive statistics such as frequencies, percentage and graphs are used for the analysis of the research questions while the hypotheses testing were done with Chi-Square. SPSS (Statistical Package for Social Sciences) computer software was used to run the analyses. The hypotheses were tested at 0.05 level of significance. At $5 \%$ level of significance, reject null hypotheses for tests with probability estimates lower than $5 \%$ (0.05) and conclude that they are statistically significant. Otherwise, we accept (when probability estimates are above 0.05 ) and conclude that there is no overall statistically significance.

\subsection{Introduction}

\section{Presentations And Interpretation Of Results}

Sixty three (63) copies of the questionnaire were administered to management officers of the 21 selected manufacturing firms in Anambra State. Twenty one copies were administered to each cluster of which 3 copies went to each of the seven firms in each cluster (zone). All the 63 copies distributed were well completed and returned. The percentage of the useable copies of the questionnaire was 100 percent.

\subsection{Socio-Demographic Characteristics Of The Study}

Table 4.1 results from the analyses of the socio-demographic characteristics of the respondents indicated that majority of the respondents are male suggesting that most of the management teams of manufacturing firms are male. Moreover, the respondents concentrated within the age bracket 26 to 41 years. Most of the respondents were persons with secondary school educational qualification following by persons with primary school educational background. This implies that most of the manufacturing firms in Anambra State are managed by persons with low educational background. 
TABLE 4.1: Socio-demographic characteristics

\begin{tabular}{|c|c|c|}
\hline Variables & Frequencies & Percentage (\%) \\
\hline \multicolumn{3}{|l|}{ Gender } \\
\hline Male & 55 & 67.3 \\
\hline Female & 8 & 12.7 \\
\hline \multicolumn{3}{|l|}{ Age } \\
\hline $18-25$ years & 9 & 14.3 \\
\hline $26-33$ years & 31 & 49.2 \\
\hline $34-41$ years & 19 & 30.2 \\
\hline Above 41 years & 4 & 6.3 \\
\hline \multicolumn{3}{|l|}{ Education } \\
\hline No formal education & 6 & 9.5 \\
\hline Primary & 19 & 30.2 \\
\hline Secondary & 22 & 34.9 \\
\hline Diploma/Post Secondary & 9 & 14.3 \\
\hline First Degree & 4 & 6.3 \\
\hline Post-graduate & 3 & 4.8 \\
\hline \multicolumn{3}{|l|}{ Location } \\
\hline Awka & 21 & 33.33 \\
\hline Onitsha & 21 & 33.33 \\
\hline Nnewi & 21 & 33.33 \\
\hline \multicolumn{3}{|l|}{ Cadre } \\
\hline Manager & 21 & 33.33 \\
\hline Others & 42 & 66.70 \\
\hline \multicolumn{3}{|c|}{ Years of service in the company } \\
\hline Less than 5 years & 8 & 12.7 \\
\hline Between 5 to 10 years & 20 & 31.7 \\
\hline Between 11 to 20 years & 29 & 46.9 \\
\hline Above 20 years & 6 & 9.5 \\
\hline
\end{tabular}

The locations of the respondents were evenly distributed among Awka, Onitsha and Nnewi zones scattered across the LGAs in Anambra State. The respondents fall into staff cadre of manager and other senior staff of which most of them have spent 11 to 20 years in the firms

\subsection{Analyses Of Research Questions}

\section{Usage of Strategic Management by Manufacturing Firms}

Research Question 1: Is strategic management practiced by manufacturing firms in Anambra State of Nigeria?

TABLE 4.2:

\begin{tabular}{|c|c|c|c|c|c|c|c|}
\hline $\mathbf{S} / \mathbf{N}$ & Variable & SA & A & $\mathbf{U}$ & D & SD & Remarks \\
\hline 7 & $\begin{array}{l}\text { Structured planning } \\
\text { Mechanism }\end{array}$ & $\begin{array}{l}4 \\
(6.3)\end{array}$ & $12(19.0)$ & $\begin{array}{l}15 \\
(23.8)\end{array}$ & $\begin{array}{l}27 \\
(42.9)\end{array}$ & $\begin{array}{l}5 \\
(7.9)\end{array}$ & Disagreement \\
\hline 8 & $\begin{array}{l}\text { Has a written vision and mission } \\
\text { statement }\end{array}$ & $1(1.6)$ & $20(31.7)$ & $5(7.9)$ & $\begin{array}{l}35 \\
(55.6)\end{array}$ & $\begin{array}{l}2 \\
(3.2)\end{array}$ & Disagreement \\
\hline 9 & $\begin{array}{l}\text { Has resources control team that } \\
\text { allocates and control resources } \\
\text { use }\end{array}$ & $\mathbf{0}$ & $5(7.9)$ & 7 (11.1) & $40(63.5)$ & (11 & Disagreement \\
\hline 10 & $\begin{array}{l}\text { Bases decisions and actions on } \\
\text { formulated organizational } \\
\text { policies }\end{array}$ & $\mathbf{0}$ & $3(4.8)$ & $16(25.4)$ & $33(52.4)$ & $\begin{array}{l}11 \\
(17.5)\end{array}$ & Disagreement \\
\hline
\end{tabular}

\section{Source: Computation from SPSS 17 Analysis}

Questionnaire items 7, 8 and 10 were used to address research question one. The responses to research question one is shown in Table 4.2 above. The study showed that majority of the firms in Anambra State does not adopt strategic management.

This is evident from the results which indication that majority of the respondents staff of the firms were in disagreement that their firms does not have structured planning mechanism, written down visions and mission statement, resource control team, and does not based decisions on formulated policies. Ticking disagreement to these variables implies that these firms do not adopt them in their management processes. This equally means that strategic management is not in use in these sample firms. 
4.4 Relationship between Level of Competition and Adoption of Strategic Management Research Question 2: What is the effect of strategic management on level of competitions?

TABLE 4.3

\begin{tabular}{|l|l|l|l|l|l|l|l|}
\hline $\begin{array}{l}\text { S/ } \\
\text { N }\end{array}$ & Variable & SA & A & U & D & SD & Remarks \\
\hline $\mathbf{1 1}$ & $\begin{array}{l}\text { Do things that give us edge } \\
\text { over our rivals }\end{array}$ & $\begin{array}{l}\mathbf{1 8} \\
(28.6)\end{array}$ & $\begin{array}{l}\mathbf{3 8} \\
(\mathbf{6 0 . 3})\end{array}$ & $\begin{array}{l}\mathbf{3} \\
\mathbf{( 4 . 8 )}\end{array}$ & $\begin{array}{l}\mathbf{4} \\
(\mathbf{6 . 3})\end{array}$ & $\mathbf{0}$ & Agreement \\
\hline $\mathbf{1 2}$ & $\begin{array}{l}\text { Our product is always } \\
\text { available than other rival } \\
\text { products }\end{array}$ & $\mathbf{0}$ & $\begin{array}{l}\mathbf{8} \\
(\mathbf{1 2 . 7 )}\end{array}$ & $\begin{array}{l}\mathbf{2 2} \\
\mathbf{( 3 4 . 9 )}\end{array}$ & $\begin{array}{l}\mathbf{3 3} \\
(\mathbf{5 2 . 4})\end{array}$ & $\mathbf{0}$ & Disagreement \\
\hline $\mathbf{1 3}$ & $\begin{array}{l}\text { Has variety of marking } \\
\text { strategies }\end{array}$ & $\begin{array}{l}\mathbf{1 2} \\
\mathbf{( 1 9 . 0 )}\end{array}$ & $\begin{array}{l}\mathbf{3 1} \\
\mathbf{( 4 9 . 2 )}\end{array}$ & $\begin{array}{l}\mathbf{1 2} \\
(\mathbf{1 9 . 0})\end{array}$ & $\mathbf{8 ( 1 2 . 7 )}$ & $\mathbf{0}$ & Agreement \\
\hline
\end{tabular}

Source: Computation from SPSS 17 Analysis

The research question two tries to find out whether the adoption of strategic management has relationship with the level of firms competitions. Questionnaire items numbers 11, 12 and 13 were used to analyze research question two. The respondents were of the view that adoption of strategic management will enhance the ability of firms to do things that gives them edge over their rivals and as well enable them to adopt variety of marketing strategies. The results from question item 12 indicated that none of the firms have an edge over the distribution strategy for their products; hence none of them could make their product more available in the market than its rival. These responses imply that there is intense competition among the manufacturing firms in Anambra State.

4.5: Relationship between Organizational Performance and Adoption of Strategic Management Research Question 3: What is the effect of strategic management on organizational performance?

TABLE 4.4:

\begin{tabular}{|l|l|l|l|l|l|l|l|}
\hline S/N & Variable & SA & A & U & D & SD & Remarks \\
\hline $\mathbf{1 4}$ & $\begin{array}{l}\text { Strives for higher net profits } \\
\text { each session }\end{array}$ & $\mathbf{3 ( 4 . 8 )}$ & $\mathbf{4 8}(\mathbf{7 6 . 2})$ & $\mathbf{1 0}(\mathbf{1 5 . 9 )}$ & $\mathbf{2 ( 3 . 2 )}$ & $\mathbf{0}$ & Agreement \\
\hline $\mathbf{1 5 .}$ & $\begin{array}{l}\text { Effective in dealing with its } \\
\text { customers }\end{array}$ & $\mathbf{1 6 ( 2 5 . 4 )}$ & $\mathbf{2 1 ( 3 3 . 3 )}$ & $\mathbf{1 5 ( 2 3 . 8 )}$ & $\mathbf{1 7}(\mathbf{1 7 . 5})$ & $\mathbf{0}$ & Agreement \\
\hline
\end{tabular}

Source: Computation from SPSS 17 Analysis

Research question three was answered with questionnaire items 14 and 15 . The research question asked whether adoption of strategic management relationship with organizational performance. Responses from the analyses were shown in Table 4:4. The results showed that adoption of strategic management will enhance profit and also engender effectiveness in customer relations. This implies that strategic management can have positive relationship with performance of manufacturing firms in Anambra State.

\section{6: Hypotheses Testing}

4.4.1 Adoption of Strategic Management and Level of Competition

Ho 1: Adoption of strategic management does not have effect on the level of competition of manufacturing firms.

Hypothesis one was testing with questionnaire item number 11.

Test Statistics

\begin{tabular}{|l|r|}
\hline & $\begin{array}{l}\text { Q.11. Do things that give us edge over } \\
\text { our rivals }\end{array}$ \\
\hline Chi-Square & \\
Df & $\mathbf{5 0 . 8 4 1}$ \\
Asymp. Sig. & $\mathbf{3}$ \\
\hline Mean & $\mathbf{. 0 0 0}$ \\
\hline
\end{tabular}

a. $\quad 0$ cells $(.0 \%)$ have expected frequencies less than

5. The minimum expected cell frequency is 15.8.

The value of the mean was 1.88 which is approximately 2 . The value of 2 indicates "agree" to the research question. This implies that adoption of strategic management influences competitiveness. The ChiSquare test is 50.841 with P. value of 0.000 . The P.value is below the $5 \%$ level of significance for this study. Therefore, the study rejects the null hypothesis that adoption of strategic management does not have effect on the level of competition of manufacturing firms. The study therefore concludes that strategic management has significant effect on the competitiveness of manufacturing firms. 
4.4.2 Strategic Management and Organizational Performance

H02: Adoption of strategic management does not have significant effects on organizational performance

Hypothesis two was testing with questionnaires item number 14

\section{Test Statistics}

\begin{tabular}{|c|c|}
\hline & $\begin{array}{l}\text { Q.14. Strives for higher net profits } \\
\text { each session }\end{array}$ \\
\hline Chi-Square & $90.460^{\mathrm{a}}$ \\
\hline & 3 \\
\hline Asump. Sig. & .000 \\
\hline Mean & 2.175 \\
\hline
\end{tabular}

a. o cells $(.0 \%)$ have expected frequencies less than

5. The minimum expected cell frequency 15.8 .

The mean of the response is 2.175 , which is approximately 2 . This indicates "agree" to question on whether strategic management has effect on firm performance. The test of hypothesis with Chi-Square indicated that $X^{2}=90.460$ with p.value of 0.000 . The significance value of the $z$-test is below the $5 \%$ level of significance stipulated for this study. Since the level of significance of the responses is below the 5\%, the study rejects the null hypothesis that adoption of strategic management does not have significant effect on organizational performance. The study therefore concluded that strategic $\mathrm{c}$ management has significant effect on organizational performance for manufacturing firms.

\subsubsection{Strategic Management and Structural Development of an Organization}

Ho3: Adoption of strategic management does not have significant effect on structural development of an organization.

Hypothesis three was testing with questionnaire item number 16

Test Statistics

\begin{tabular}{|l|rr|}
\hline & Q. 16. Strives to creates units to handle & unique function \\
\hline Chi - Square & $\mathbf{2 0 . 0 9 5}^{\mathrm{a}}$ \\
Df & $\mathbf{2}$ \\
Asymp. Sig. & $\mathbf{0 0 0}$ \\
\hline Mean & & $\mathbf{2 . 3}$ \\
\hline
\end{tabular}

a. 0 sells $(.0 \%)$ have expected frequencies

less than 5 . The minimum expected cell

Frequency is 21.0 .

The mean of the responses on whether strategic management has effect on structural development of firms is 2.3. This indicated that strategic management can enhance structural development of firms. The hypothesis test showed that the Chi-Square test value is 20.09 with p.value of 0.000 . The p.value is less than the $5 \%$ significance test value stipulated for this study. The study therefore rejected the null hypothesis that adoption of strategic management does not have significant effect on structural development of an organization. The study then concludes that strategic management has significant effect on the structural development of manufacturing firms.

\section{Summary Of Findings, Conclusion And Recommendations \\ 5.1 Summary of Findings}

Studies have shown that achieving a competitive advantage position and enhancing firm performance relative to their competitors are the main objectives that business organizations should strive to attain. Also, the idea that strategy content influences organizational performance is a central element of generic management theory. To remain competitively advantaged, studies have equally suggested the use of strategic management. This is because strategic management identifies the purpose of the organization and the plans and actions to achieve the purpose.

Despite these, no research work has targeted to investigate the impact of the broad subject of strategic management on organizational growth and development in Nigeria. Existing studies in Nigeria, aimed at human resource development (e.g. Oladipo and Abdulkadir, 2010; Oladipo and Abdulkadir, 2011, Abdulkadir, 2012). Related studies on this study were on strategic planning (an off shoot of strategic management) (see Ilesanmi, 2011 and Akinyele \& Fasogbon, 2007). Of these studies in Nigerian, none accessed the impact strategic management of planning on manufacturing sub-sector of the economy. More so, scanty studies have been done 
on strategic management in Africa (e.g Raduan, Jegak, Haslinda and Alimin, 2009 in Malaysia, and Gichunge, 2010 from Kenya) did not cover indeed, the areas that the objectives of this work covers.

Based on the above premise, the study investigated the level of use and effect of strategic management on manufacturing firms in Anambra State. Following assertions that strategy can be characterized as senior managers' response to the constraints and opportunities that they face, this study used sampled responds from only managers and senior staff cadre of manufacturing firms. Descriptive and Chi - Square test indicated the following findings:

1. Strategic management is not common among the manufacturing firms in Anambra State.

2. Strategic management influences competitiveness and that adoption of strategic management has significant effect on competitiveness of manufacturing firms.

3. Strategic management has effect on firm performance and that adoption of strategic management has significant effect on organizational performance for manufacturing firms.

\section{Conclusion}

Strategic management is not yet a common business practice among manufacturing firms in Anambra State. Nonetheless, strategic management has been identified has veritable tool for improving the competitiveness, performance levels, and structural development of manufacturing firms in Anambra State in particular and Nigeria in Nigeria.

\section{Acknwnoledgement}

It is my pleasure to acknowledge these persons who in various ways contributed to the success of this research work. My sincere gratitude goes to God Almighty whom I put my trust and the solid Rock which I stand.

My profound gratitude also goes to my husband Okey Muogbo and my children whose sacrifice and self denial resulted to my academic fulfillment.

I am profoundly grateful to my mentor Dr V. N. Ezeabasili for giving attention to areas that needed correction, which led to the successful completion of this research work.

Special thanks also to my wonderful friends Bernard A. U. , I.G Ezeamama, Jacobs C.J etc who stood strongly by me throughout the course of writing this research work. May God bless and guide you all in Jesus name. Amen.

\section{Recommendations}

The study recommended that further studies be carried out in Nigeria to investigate the causes of nonadoption of strategic management in Anambra State in particular and Nigeria in general. The causes of this when known and curbed, small and median scale industries in Nigerian might become more competitive in boosting the development of Nigerian economy.

The entrepreneurial centre and business schools in Nigeria should incorporate strategic management principles into their curricula. This will engender sound managerial know-how and boost the performance and competitiveness of firms in Nigeria.

\section{References}

[1] ABDULKADIR D.S. (2012). Strategic Human Resource Management and Organizational performance in the Nigerian Insurance Industry: The Impact of Organizational Climate, Business Intelligence Journal. 5 (1), 8 - 20. Retrieved from www.saycocorporativo.com/saycoUK/BIJ/journal/Vol5No1/Article1.pdf [4]

[2] AKINYELE S.T. AND FASOGBON O.I. (2007). Impact of Strategic Planning on Organizational Performance and Survival. Research Journal of Business Management, 1 62-71. Retrieved from http://scialert.net/abstract/?doi=ribm.2007.62.71. [4]

[3] DAVID, F.R. (2005). Strategic Management: Concepts and Cases, Tenth Edition. Prentice Hall, Pearson Education International, 2005. [5]

[4] ZAINAL ABIDIN MOHAMED (2005). Pengurusan Strategik. Siri Pengurusan dan Pentadbiran Utusan. Utusan Publications \& Distributors Sdn. Bhd., Kuala Lumpur. [5]

[5] RADUAN, C.R., JEGAK, U., HASLINDA, A. AND ALIMIN, I.I. (2009). Management, Strategic Management Theories and the Linkage with Organisational Competitive Advantage from the Resource-Based View. European Journal of Social Sciences, 11 (3), 402- 418. [5]

[6] PORTER, M.E. AND KRAMER, M.R. (2006). Strategy and society: The link between competitive advantage and corporate social responsibility. Harvard Business Review, December 2006. [6]

[7] BARNEY, J.B. (1995). Looking inside for competitive advantage. Academy of Management Executive, Vol. 9, No. 4, pp.49-61. [6]

[8] AINUDDIN, R.A., BEAMISH, P.W., HULLAND, J.S. AND ROUSE, M.J. (2007). Resource attributes and firm performance in international joint ventures .Journal of World Business, 42,47-60. [6]

[9] ASKARANY, D. AND YAZDIFAR, H. (2012). Strategic Management Tools and Organisational Performance, Paper presented at session title, Research Interaction Forum 1 in Washington DC Seed of Innovation, American Accounting Association Annual Meeting and Conference on Teaching and Learning Accounting, Monday August 6, 2012 http://aaahq.org/AM2012/abstract.cfm?submissionID=576 [7]

[10] GICHUNGE, E.M. (2010). The Effect of Formal Strategic Management on Organisational Performance: A study of selected Medium Sized Manufacturing Enterprises inNairobi, Kenya. Retrieved from 
[11] http://www.ku.ac.ke/schools/graduate/images/stories/docs/abstracts/2010/june/the_effect_of_formal_strategic_management.pdf [7]

[12] OLATOKUN, W.M. AND GBINEDION, L.J. (2009). The Adoption of Automatic Teller Machines in Nigeria: An Application of the Theory of Diffusion of Innovation, Issues in Informing Science and Information Technology, 6, 373-393. [9]

[13] ATIKU, S.O., GENTY, K.I. AND AKINLABI, B.H. (2011). Effect of Electronic Banking on Employees' Job Security in Nigeria, European Journal of Humanities and Social Sciences, 4(2), 68-84. [9]

\section{APPENDIX}

Areas in the three senatorial zones in Anambra State List of Manufacturing Firms in Nnewi Zone, Anambra State, Nigeria

\begin{tabular}{|l|l|l|}
\hline S/N & FIRMS & SAMPLE \\
\hline 1 & Cutix Plc & 3 \\
\hline 2 & Rimco Industries Ltd (Chicason Group) & 3 \\
\hline 3. & Innoson Motors Manufacturing Company & 3 \\
\hline 4. & Ibeto Group of Company & 3 \\
\hline 5. & Tummy Tummy Industries/Event Ltd & 3 \\
\hline 6. & OTC Industries & 3 \\
\hline 7. & Coscharis Industries & 3 \\
\hline & Total Sample & 21 \\
\hline
\end{tabular}

List of Manufacturing Firms in Awka Zone, Anambra State, Nigeria

\begin{tabular}{|l|l|l|}
\hline S/N & FIRMS & SAMPLE \\
\hline 1 & Ozalla Plastics Enterprises Ltd & 3 \\
\hline 2 & Juhel Pharmaceutical Coy & 3 \\
\hline 3. & Millennium Industries Ltd & 3 \\
\hline 4 & Winco Foam Industries Ltd & 3 \\
\hline 5 & Beloxxi Industries Ltd & 3 \\
\hline 6 & Amutolo Industries Ltd & 3 \\
\hline 7 & Tonimax Industies Ltd & 3 \\
\hline & Total Sample & 21 \\
\hline
\end{tabular}

List of Manufacturing Firms in Awka Zone, Anambra State, Nigeria

\begin{tabular}{|l|l|l|}
\hline S/N & FIRMS & SAMPLE \\
\hline 1 & Dozzy Industries & 3 \\
\hline 2 & Whiz Products Ltd & 3 \\
\hline 3. & Krisoral Industries Ltd & 3 \\
\hline 4 & General Cotton Mills Ltd & 3 \\
\hline 5. & Hugo Solid Mineral Process Industry Ltd & 3 \\
\hline 6. & Inland Doors Aluminium Ltd & 3 \\
\hline 7 & Niger Chemicals Ltd & 3 \\
\hline & Total Sample & 21 \\
\hline
\end{tabular}

